\title{
RANCANGAN STRATEGI PENDIDIKAN BERBAHASA SANTUN DALAM PEMBELAJARAN BERBICARA
}

\author{
Taufik Hidayat ${ }^{1}$, Rina Agustini ${ }^{2}$ \\ Universitas Galuh \\ Surel: taufikplus4@gmail.com ${ }^{1}$ \\ rinaagustina1408@gmail.com ${ }^{2}$
}

\begin{abstract}
Abstrak
Kajian ini bertujuan untuk menggambarkan rancangan strategi pendidikan berbahasa santun pada pembelajaran berbicara. Kesantunan dalam kajian ini mengacu pada konsep berbicara dalam Al-Quran, prinsip kerjasama (Grice, 1975), prinsip kesantunan (Leech, 1993) dan konsep pendidikan karakter (Gunawan, 2015). Kajian ini menggunakan pendekatan kualitatif interaktif dengan metode deskriptif analitik. Data diperoleh melalui studi pustaka dan observasi kepada 59 responden yang telah mengikuti perkuliahan keterampilan berbicara di salah satu perguruan tinggi swasta Jawa Barat, Ciamis. Adapun hasilnya yakni, penerapan strategi pendidikan berbahasa santun pada mata kuliah keterampilan berbicara dilakukan melalui tiga fase, yakni (1) komitmen, (2) penerapan dan latihan, (3) kedisiplinan. Ketiga fase tersebut, diperkuat dengan pengkondisian iklim belajar yang santun dan pemilihan bahan ajar yang memiliki nilai kesantunan tinggi.
\end{abstract}

Kata kunci: strategi, pendidikan, santun, berbahasa, berbicara.

\section{Abstract}

This study aims to describe the design of polite language education strategies in learning to speak. Politeness in this study refers to the concept of speaking in the Koran, the principle of cooperation (Grice, 1975), the principle of politeness (Leech, 1993) and the concept of character education (Gunawan, 2015). This study uses an interactive qualitative approach with descriptive analytic methods. Data obtained through literature study and observation of 59 respondents who have taken courses in speaking at Galuh University. As the results, the design of polite language education strategies in the speaking subject istcarried out through three phases, namely (1) commitment, (2) application and training, (3) discipline. These three phases are reinforced by the conditioning of polite learning climate and the selection of teaching materials that have high politeness values.

Keywords: strategy, education, polite, language, speak.

\section{PENDAHULUAN}

Manusia sebagai makhluk sosial berkomunikasi, mengungkapkan pikiran, dan perasaannya melalui bahasa. Kesantunan berbahasa merupakan hal penting yang dibutuhkan dalam berkomunikasi (Nisja, 2009; Soepriatmadji, 2012; Gunawan, 2013; Mulatsih, 2014). Hal ini disebabkan kesantunan berbahasa merupakan 
unsur yang kritis dalam pembentukan identitas setiap individu dan pada akhirnya menjadi identitas suatu bangsa (Mulatsih, 2014).

Berbahasa santun dalam AlQuran berhubungan dengan cara pengucapan, perilaku, kosa kata, dan sesuai dengan situasi dan kondisi. Konsep berbahasa yang tertuang dalam Al Quran sedikitnya terdapat enam prinsip. Prinsip tersebut yakni, (1) qaulan ma'rufa (QS 4:8) yaitu berbicara dengan menggunakan bahasa yang baik, yang menyenangkan hati, (2) qaulan sadida (QS 4:9) yaitu berbicara dengan benar, (3) qaulan baligha (QS 4:63) yaitu berbicara dengan menggunakan ungkapan yang tepat atau mengena, (4) qaulan karima (QS 17:23) yaitu berbicara dengan menggunakan kata-kata yang berisi dan penuh hormat, (5) qaulan masyura (QS 17:28) yaitu berbicara dengan baik dan pantas agar orang lain tidak kecewa, dan (6) qaulan layyina (QS 20:44) yaitu berbicara dengan lembut.

Tidak berbeda jauh secara subtansi dengan prinsip di atas, Grice (1975) mengemukakan prinsip kerja sama yang terdiri atas empat maksim, yaitu (1) maxim of quantity, menghendaki agar setiap partisipan memberikan informasi yang cukup, yakni sebanyak keperluan mitra tutur; (2) maxim of quality, mengikat setiap partisipan untuk menyampaikan hal yang sebenarnya atau ditunjang dengan data dan fakta; (3) maxim of relevance, mengikat setiap partisipan memberikan kontribusi (informasi) yang relevan dengan hal atau topik yang sedang dibicarakan; (4) maxim of manner, mengikat setiap partisipan untuk mengungkapkan informasi secara benar, langsung, tidak kabur, tidak cacat, dan tidak berlebihan.

Sementara dilihat dari cara penyampaiannya, Leech (1993) mengemukakan prinsip berbahasa santun ke dalam enam maksim. Keenam maksim tersebut yakni, (1) maksim kebijaksanaan, (2) maksim kedermawanan, (3) maksim penghargaan, (4) maksim kesederhanaan, (5) maksim permufakatan, dan (6) maksim kesimpatian.

Bangsa Indonesia sejak dulu dikenal dengan bangsa yang berkarakter santun. Namun secara perlahan identitas tersebut mulai terkikis dengan banyaknya prilaku tidak santun dari warganya. Culpeper (1996) menegaskan bahwa ketidaksantunan merupakan lawan dari kesantunan atau dengan kata lain cara yang dipakai untuk merusak hubungan sosial atau keharmonisan pengguna bahasa.

Masalah kesantunan berbahasa berhubungan erat dengan menjaga harga diri (Brown dan Levinson, 1987). Ketidaksantunan berbahasa berdasarkan sudut pandangan Islam, ditandai dengan pelanggaran terhadap aturan yang tertuang dalam Al-Quran dan Hadist. Bentuk ketidaksantunan tersebut Sodiantaranya, ketakaburan, kebohongan, dan fitnah yang melanggar aturan dalam agama. Ketidaksantunan tersebut berkembang dalam berbagai variasi seperti menggunjing, memperolok, menfitnah, mengumpat dan sebagainya (Ngalim, 2014).

Variasi ketidaksantunan tersebut terasa kental seiring perkembangan teknologi komunikasi. Kata-kata 
menggunjing, memperolok, menfitnah, mengancam, seakan-akan tidak bisa terbendung di berbagai media sosial, apalagi bercampur dengan kepentingan politik yang tidak bertanggung jawab seperti suasana di tahun pemilihan umum. Mahasiswa sebagai insan akademis seharusnya berperan menjadi pelopor untuk menjaring penyebaran informasi tersebut. Namun karena berbagai alasan, sebagian mereka justru terjebak ikut menyebarkan bahkan mengkreasinya untuk kepentingan pribadi atau golongan. Jika fenomena ini dibiarkan terus-menerus, maka akan berdampak rusaknya karakter, dan memicu perpecahan bangsa.

Salah satu faktor yang menimbulkan rendahnya kualitas berbahasa seseorang antara lain adanya perubahan situasi masyarakat yang semakin kompleks dan buruk. Di sisi lain, pembinaan berbahasa yang berkualitas kurang mendapatkan perhatian penuh dari berbagai lapisan masyarakat (Azis, 2001). Menghadapi kenyataan tersebut, pembinaan berbahasa santun merupakan hal penting untuk dilaksanakan sehingga dapat memperbaiki berbahasa mahasiswa. Lebih jauh lagi, pembinaan tersebut dapat menjadikan mahasiswa terbiasa menggunakan bahasa santun.

Berdasarkan uraian di atas, peneliti bermaksud untuk menemukan pola pembinaan berbahasa santun dalam pembelajaran berbicara di perguruan tinggi.

\section{METODE}

Penerapan strategi berbahasa santun ini dilaksanakan di salah satu universitas swasta di Jawa Barat,
Ciamis. Subjek penelitian berjumlah 59 mahasiswa yang terbagi dalam tiga kelas. Kajian ini menggunakan pendekatan kualitatif interaktif dengan metode deskriptif analitik. Adapun teknik pengumpulan data yang digunakan dalam kajian ini sebagai berikut.

1. Studi pustaka digunakan untuk memperkaya teori strategi pembelajaran dan teori berbahasa santun. Teori-teori tersebut didapat dari artikel-artikel jurnal maupun buku-buku referensi.

2. Observasi dilakukan untuk mengamati mahasiswa dalam berkomunikasi dan proses pembelajaran berbicara di kelas.

3. Wawancara digunakan untuk memperoleh informasi tentang pandangan mahasiswa mengenai berbahasa santun dan penerapan strategi berbahasa santun.

\section{HASIL DAN PEMBEHASAN Strategi Pendidikan Berbahasa Santun dalam Pembelajaran Berbicara}

Santun dalam berbahasa berkaitan erat dengan sikap atau karakter. Berbahasa santun bukan bawaan sejak lahir, sehingga dapat dibentuk dan dikembangkan. Berbahasa santun tidak ${ }^{a}$ bisatrdibentuk dengan cara instan. Pendidikan ini merupakan sebuah proses. Proses pendidikan ini cenderung tidak akan pernah tersentuh secara nyata jika hanya bersifat informasi tanpa adanya tindakan. Oleh karena itu, kunci dari pendidikan karakter adalah adanya komitmen, penerapan, dan kedisiplinan, (Gunawan, 2015). 
Membentuk dan menyepakati komitmen menjadi pondasi dalam tahap pembelajaran berbahasa santun. Pendidik harus mampu berkomitmen dan mengajak peserta didik untuk memiliki komitmen yang kuat untuk menggunakan bahasa santun. Langkah yang dilakukan untuk membangun komintmen tersebut ialah dengan memberikan penjelasan pentingnya penggunaan berbahasa santun ditinjau dari berbagai sudut pandang (religius, sosial, profesional).

Penjelasan pentingnya berbahasa santun dapat diawali dari sudut pandang agama. Sang Pencipta menyuruh umatnya untuk berperilaku sopan, santun dan saling menyayangi. Bahkan salah satu nama Tuhan yang kita kenali adalah Ar Rahman (Maha Pengasih) dan Ar Rahim (Maha Penyayang). Semua kitab suci beragama tidak luput untuk memerintahkan umatnya berbahasa secara santun. Penjelasan berikutnya dapat menggunakan sudut pandang sosial dan profesional. Dengan berbahasa santun keakraban dan kerukunan dapat tercapai.

Komitmen lain yakni, pendidik dan peserta didik siap menggunakan dan membiasakan untuk bahasal IImiah santun terutama dalam proses pembedidikan lajaran. Adapun untuk rancangan tujuan pembelajaran disusun sebagai berikut, a) peserta didik memiliki sikap, pengetahuan, dan keterampilan berbicara yang santun; b) peserta didik dapat memperktekan sikap dan keterampilan berbahasa santun dalam kehidupan sehari-hari.

Setelah adanya komitmen, penerapan menjadi langkah berikutnya.
Pengkondisian suasana belajar yang santun menjadi prioritas utama dalam langkah penerapan. Hal ini dapat dilakukan dengan membiasakan berbahasa santun oleh pendidik dan peserta didik. Pembiasaan ini sebagai metode peniruan dan keteladanan bagi peserta didik. Pendidik memberikan poin tambah berupa pujian saat siswa berbahasa santun di kelas. Sebaliknya pendidik menegur atau mengkritik siswa yang tidak menggunakan bahasa santun saat proses pembelajaran.

Penerapan berikutnya pendidik menyiapkan materi khusus tentang bahasa santun. Selain itu dapat mengaitkan bahan ajar dengan nilainilai kesantunan. Hal ini bisa dilakukan dengan memberikan contohcontoh berupa teks yang memiliki tingkat kesantunan tinggi.

Penerapan lainnya dalam evaluasi pembelajaran. Evaluasi pembelajaran berbicara didesain untuk mengukur dan meningkatkan aspek keterampilan dan sikap dalam berbicara. Alat evaluasi yang digunakan berupa nontes jenis unjuk kinerja untuk keterampilan berbicara dan observasi untuk penggunaan berbahasa santunnya.

Terakhir yakni kedisiplinan dalamasa komitmen dan penerapan. Langkah ini tidak kalah pentingnya dengan dua langkah di atas. Komitmen dan penerapan yang kontinu dan konsisten menjadi langkah penting untuk membiasakan peserta didik untuk terbiasa berbahasa santun. hal ini sesuai dengan yang dikatakan Aristoteles dalam Covey (2013) bahwa kita adalah apa yang kita kerjakan berulang-ulang. Lebih 
dalam Covey (2013) mengatakan taburlah gagasan, tuailah perbuatan; taburlah perbuatan, tuailah kebiasaan; taburlah kebiasaan, tuailah karakter; taburlah karakter, tuailah nasib. Oleh karena itu, semakin sering dan konsisten berbahasa santun, maka akan semakin kuat karakter santun dalam diri peserta didik.

\section{PENUTUP}

\section{Simpulan}

Strategi pendidikan berbahasa santun pada mata kuliah keterampilan berbicara diterapkan melalui tiga fase, yakni 1) membuat dan menyepakati komitmen untuk senantiasa berbahasa santun dalam proses pembelajaran maupun kegiatan sehari-hari; 2) penerapan yakni, proses pembelajaran ditunjang dengan pengkondisian iklim belajar yang santun dan pemilihan bahan ajar yang memiliki nilai-nilai kesantunan; 3) kedisiplinan dalam komitmen dan penerapan.

\section{DAFTAR PUSTAKA}

Al- Qur'ân al- Karîm. Departemen Agama RI, Al-Qur'an dan Terjemahannya, Bandung: $\mathrm{CV}$. Penerbit Jumanatul

Brown, Penelope and Stephen C.I llmiah Levinson. 1987. Politeness: some universals in language usage. Cambridge: Press Syndicate of the University of Cambridge.

Covey, Stephen R. 2013. The 7 Habits of Highly Effective People. Pamulang: Binarupa Aksara Publisher

Culpeper, Jonathan. 1996. Toward an anatomy of impoliteness. Journal of Pragmatics 25, hlm 349-367.
Grice, H. P. 1975. Logic and Conversation. In P. Cole, \& J. L. Morgan. (Eds.), Syntax and Semantics, Vol. 3, hlm. 41-58. New York: Academic Press.

Gunawan, Fahmi. 2013. Wujud Kesantunan Berbahasa Mahasiswa Terhadap Dosen di STAIN Kendari: Kajian Sosiopragmatik. Journal Arbitrer, Vol. 1 No. 1 Oktober 2013, hlm 8-18.

Gunawan, Imam. 2015. Pendidikan Karakter. Universitas Negeri Malang. Diakses dari http://fip.um.ac.id/wpcontent/uploads/2015/12/15.1_Pe ndidikan-Karakter.pdf.

Leech, Geoffrey. 1993. PrinsipPrinsip Pragmatik. Jakarta: Universitas Indonesia.

Mulatsih, Sri. 2014. Ketidaksantunan Berbahasa Pada Pesan Singkat (SMS) Mahasiswa ke Dosen. Prosiding Seminar Nasional "Ketidaksantunan Berbahasa dan Dampaknya dalam Pembentukan Karakter". Universitas Muhammadiyah Surakarta.

Ngalim, Abdul. 2014. Ketidaksantunan dan Kesantunan Berbahasa dalam Perspektif Islam Serta Dampaknya Terhadáp Pembentukan Karakter. Prosiding Seminar Nasional "Ketidaksantunan Berbahasa dan Dampaknya dalam Pembentukan Karakter". Universitas Muhammadiyah Surakarta.

Nisja, Indriani. (2009). 'Kesantunan Berbahasa dalam Berdiskusi Mahasiswa Jurusan Bahasa Indonesia Semester III Tahun 2007-2008 Ummy Solok'. Dalam 
Jurnal Ilmiah Tambua, Vol. VIII, No. 3, September-Desember 2009 hal 478-487.

Soepriatmadji, Liliek. 2012. Strategi

Kesantunan yang Tercermin

Dalam Model Percakapan Pada
Buku Bahasa Inggris Kelas 6 SD. Jurnal Dinamika Bahasa dan Ilmu Budaya, Vol. 7 No. 2, Juli 2012, hal 93-105

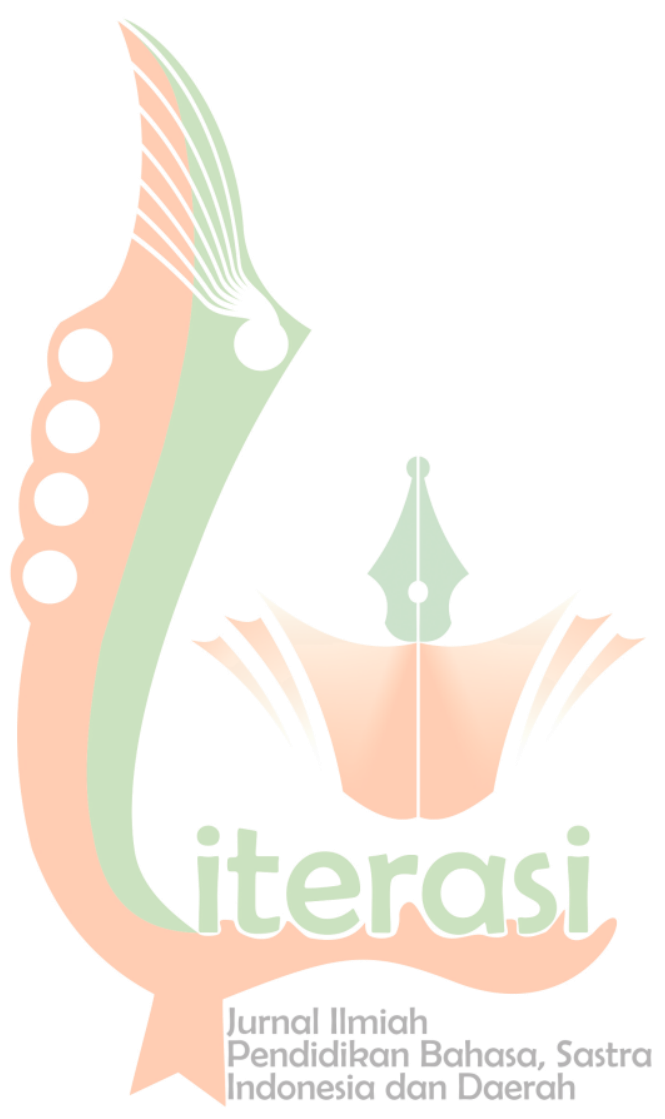

